\title{
Temporal and spatial dimensions of group entrepreneurship: the case of a craft fair as a community of practice
}

\author{
ARIANE LATOSKI ${ }^{1}$ \\ EloY EROS DA SILVA NOGUEIRA ${ }^{1}$ \\ ${ }^{1}$ Universidade Positivo / Doctorate Program in AdMINISTRATION, CURITIBA - PR, BrazIL
}

\begin{abstract}
This article proposes an analysis of the temporal and spatial dimensions of group entrepreneurship, covering aspects such as learning, qualification, and training to build the social structure dimensions around entrepreneurial practices. The study adopts the social learning theory to examine a self-managed collective enterprise working to gain space and momentum, expanding its visibility in symbolic, economic, and material terms, while facing adverse conditions of social structure and competition. The study analyzes a craft fair the artisans conduct themselves. The fair offers and sells handicrafts, occupying public space and facing the competition of shopping malls established in the same region. We adopted a qualitative methodology for in-depth study. We conclude that territorialization can be an activity or practice that defines positioning and relationships and, at the same time establishes limits and borders, creates connections and new possibilities. This type of participation promotes group or community learning, enabling the construction of social space and establishing a place for the fair in the context.
\end{abstract}

Keywords: Community of practice. Territorialization. Learning. Craft fair.

\section{Dimensões temporais e espaciais da prática empreendedora em grupo: o caso da feira de artesãs como comu- nidade de prática}

\section{Resumo}

Este artigo propõe uma análise das dimensões temporais e espaciais da prática empreendedora em grupo e da sua aprendizagem, habilitação e capacitação para construí-las na estrutura social em que tal prática se situa. Para tanto, examinamos, sob a perspectiva da teoria social da aprendizagem, um empreendimento coletivo autogerido que precisa conquistar e construir seu lugar e momento com visibilidade, em termos simbólicos, econômicos e materiais, e enfrentar as condições adversas da estrutura social e a concorrência. No caso, escolhemos uma feira conduzida pelas próprias artesãs que oferece e vende os artesanatos delas ocupando espaço público e enfrentando a vizinhança de shopping centers. Adotamos uma metodologia qualitativa para estudo em profundidade. Concluímos que a territorialização pode ser uma atividade ou prática que define posicionamento e relações e, ao mesmo tempo que estabelece limites e fronteiras, cria conexões e novas possibilidades. Esse tipo de participação promove a aprendizagem do grupo - ou da comunidade - que o habilita a construir o espaço social e a estabelecer um lugar no contexto.

Palavras-chave: Comunidade de prática. Territorialização. Aprendizagem. Feira de artesanato.

\section{Dimensiones temporales y espaciales de la práctica emprendedora en grupo: el caso de la feria de artesanas como comunidad de práctica}

\section{Resumen}

Este artículo propone un análisis de las dimensiones temporal y espacial de la práctica empresarial grupal y de su aprendizaje, calificación y formación para construirlas en la estructura social en la que se ubica dicha práctica. Para ello, examinamos, desde la perspectiva de la teoría del aprendizaje social, una empresa colectiva autogestionada que necesita conquistar y construir su lugar y momento con visibilidad, en términos simbólicos, económicos y materiales, y enfrentar las condiciones adversas de la estructura social y de la competencia. En este caso, optamos por una feria dirigida por las propias artesanas que ofrecen y venden sus artesanías, en un espacio público, en medio a los centros comerciales. Adoptamos una metodología cualitativa para un estudio en profundidad. Concluimos que la territorialización puede ser una actividad o práctica que define posicionamientos y relaciones y, al mismo tiempo que establece límites y fronteras, crea conexiones y nuevas posibilidades. Este tipo de participación promueve el aprendizaje del grupo -o de la comunidad-que le permite construir un espacio social y establecer un lugar en el contexto.

Palabras clave: Comunidad de práctica. Territorialización. Aprendizaje. Feria artesanal. 


\section{INTRODUCTION}

The notion of 'community of practice' has received increasing attention in studies on learning and organizational knowledge in Brazil. These studies reflect the interest and efforts to establish a basic conceptual framework on this issue (Ferrarini, Camargo \& Bulgacov, 2014; Mendes \& Urbina, 2015). 'Community of practice' is associated with the theory of situated learning, which proposes that knowledge and learning are achieved through acting in a given material and social context (Brown \& Duguid, 1991; Lave, 2011; Lave \& Wenger, 1991; Wenger, 2011). This notion brings the perspective that learning takes place in the context of our own experience of participation in the world, a phenomenon of our social nature. In this concept, participation represents the relationships between the social structure and the situated condition of experience in the actions that produce and reproduce such social structure (Giddens, 2003; Wenger, 2011). These relationships have continuities and discontinuities, possibilities, improvisations, and interactions. Wenger (2011) seeks a more precise conceptualization of 'community of practice,' identifying its borders and limits, what is internal and external, and its location and historical conditions. The author considers that the practice creates not only limits but also constitutes a connection. Wenger's (2011) geography of practice suggests that the community is a portion of the social structure (Wenger, 2011) and that learning is an engine to develop the practice due to its structuring character. However, as Lervik, Fahy and Eastertby-Smith (2010) and Fahy, Easterby-Smith and Lervik (2014) pointed out, the temporal and spatial dimensions seem to have received less attention in organizational studies, especially those dedicated to learning and organizational knowledge. These theories on practice describe the context as the place in which the practice finds its essential elements, and as the social structure where the practice has its sense and meaning and realizes the social world. Time and space are usually seen as elements from natural reality - part of the world - and people can experience, but not create them. This article reflects on this issue from a different point of view. The assumption here is that we can investigate time and space as elements that constitute - and are constituted by - social relations and practices. Previous reflections (Bachelard, 1978; Bourdieu, 2013; Certeau, 2014; Giddens, 2003; Harvey, 2017; Lefebvre, 1974) suggest that the ability to influence or build spatial-temporal orders is a form of social power. The practice and the community have limits and boundaries; their existence presupposes a defined space and time, in relationship with other practices and communities. The territory emerges from the action on time and space (Harvey, 2017; Mendes \& Cavedon, 2015) and brings its political, material, and symbolic dimensions to establish relations and positions with other entities of the social structure or in the context.

Territorialization, therefore, is part of the life of the community of practice and may have implications for situated learning, given its structuring nature.

This article proposes an initial analysis of the possibility that the practice of the community would need the dedication of energy and action over space and time, in order to differ from the dominant social structure. The study also explores the implications of this possibility for learning and community capacity building from the perspective of the social learning theory. The research is a case study of a craft fair. The fair is an activity of artisans that happen in a public place, and, therefore, brings the dimension of learning about making crafts, together with the action of creating and conquering a place within the collective social space.

\section{THEORETICAL FRAMEWORK}

\section{Situated learning in groups ad community of practice}

The concept of 'community of practice' has been used to understand the development of learning and as a tool to promote knowledge transfer and sharing (Nicolini, Scarbrough \& Gracheva, 2015).

Wenger, Mcdermott and Snyder (2002) developed an argument that enables analyzing social learning in workgroups where there are substantive changes, especially technological ones, and whose assessment applied to current times seems to provide questions and contributions about collective entrepreneurial action and competence, in a social context under intense and accelerated transition due to technology.

Wenger et al. (2002) considered that cultivating communities of practice in strategic areas of a company is a way of systematically managing knowledge, as the advance of science and technology creates a paradox: at the same time as the growing complexity 
of knowledge requires greater specialization and collaboration, the half-life of knowledge makes it challenging to keep up with the rapid pace of change.

Wenger et al. (2002) present three elements that provide a practical model to guide community development:

1. Domain - community development relies on the task of negotiating a shared domain. A community must ask itself: what are topics and issues that really matter?

2. Community - the community needs attention, organization, and education. What roles will people play?

3. Practice - any community with continuous interactions among people will develop some kind of practice over time. What knowledge will be shared, developed, documented? What types of learning activities will be organized?

In addition, when seeking to describe the dynamics that support the existence of a community of practice, Wenger (1998) proposed that 'domain,' 'community,' and 'practice' are present in three dimensions:

1. Shared repertoire;

2. Joint enterprise;

3. Mutual engagement.

Figure 1 represents how the elements are intertwined.

Figure 1

The three dimensions of a community

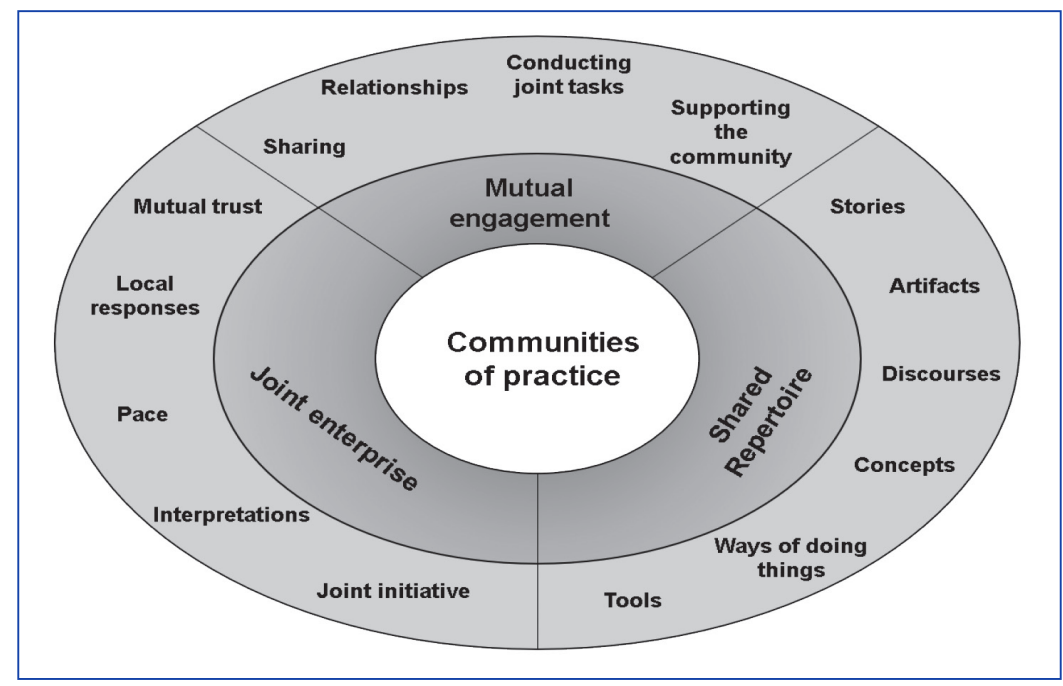

Source: Gouvêa, Paranhos and Motta (2008, p. 5, our translation).

In communities of practice, common knowledge, through mutual engagement, demonstrates the social and negotiated nature character between the tacit and the explicit in people's lives and the work environment. This feeling of identity and belonging creates, in the informal structures of the organization (Gropp, 2007), an environment that facilitates organizational learning, where knowledge and innovation occur.

For Lave and Wenger (1991), the participation in the practices of a community can be described based on a peripheral and legitimated initial position from which the inclusion starts. It is an inclusion associated with the degree of knowledge acquired by the practice in a movement toward completeness, going through different stages of group belonging (Gropp, 2005).

Note that these theories focus on a practice that occurs in an organizational environment or working conditions. The elements that constitute the learning process and the community of practice are in line with these environments and conditions. 
However, this research focuses on a collective enterprise in which a craft fair that happens in a public place is its most visible face. Craftwork does not exhaust the field of knowledge that the artisans must master. As a group, their actions must systematically (and not accidentally or occasionally) address those who are not part of their primary field of knowledge craftwork -, at a time and place that the group must build and define, considering the context.

\section{Space and time in social practices}

Spaces (and their times) are complex social constructions, dialectically based on socially produced values and meanings encompassing three aspects: a) perceptions and daily practices; b) representations and theorizations; and c) the spatial imaginary of the time lived. The collective social space is related to spatial practice (Giddens, 1985, 2003; Hagerstrand, 1975; Lefebvre, 1974).

Bourdieu $(1997,2013)$ states that social space is inscribed in the objectivity of spatial structures and simultaneously in subjective structures (schemes of action, thought, and perception). The distribution of goods, relationships, and positions combine these structures, their meanings, and values, in competing, overlapping, or contained fields. The physical space has inscribed the hierarchies defined by the social spaces. This is the symbolic reality, revealed in the territories and perpetuated by social practices. Occupying a physical space does not mean enjoying the social space or appropriating it effectively. The neo-occupant may lack the tacit or the corresponding habit; however, this may be acquired over time.

For Bachelard (1978), space and time are two sides of historical becoming and social reproduction schemes: materiality crystallizes the meanings that are attributed to time.

Harvey (2017), in turn, proposes that the processes of reproduction and transformation of society are related to the conceptions of space and time. These conceptions are the basis for maintaining power through these social processes. The author's analytical model incorporates three dialectically interrelated spheres in which spatial practice takes place: a) effective flows and interactions; b) representations in the concepts, offering intelligibility (to spatiality and temporality); and c) negotiations and reinterpretations of new meanings and representations for spatial practices.

These spheres potentially combine a) the modes of signification and reproduction, b) modes of appropriation and use of spaces, and c) the ways of dominating the possibilities of change in the production of spaces.

The work by Lefebvre (1974) inspired Lervik et al.(2010) and Fahy et al. (2014) to develop an analytical framework that takes advantage of the triadic conception of space (conceived, perceived, and lived) to study the socially constructed space. They transpose this dialectical triadic vision to study time (conceived temporal structures, established temporal practices, and lived experience of these structures and practices in specific contexts and situations). The authors verify how temporal structures influence and may synchronize organizational actions and interactions among its members and with others, and how actors can appropriate them to gain power.

\section{Social learning, territorialization, practice, and culture}

Producing craftwork is a non-industrial activity in a non-scale economy. The artisan dominates the technology or technique, and the process of imprinting a personal and direct identity on the product, even when it comes to crafts made in groups or collectively.

As highlighted by Davel, Cavedon and Fischer (2012), the artisan incorporates aesthetics, physical dexterity, mastery of technique, and planning and operation skills in their work.

The visibility and invisibility of the artist and artisan and their art are related to the dimension of the work associated with the social time-space where it is developed (Chiesa, Gois, De Luca \& Cavedon, 2015) and, thus, can be appreciated or criticized.

When studying the case of lacemakers in the municipality of Alcaçuz, in the Northeast of Brazil, from the perspective of social learning theory, Ferreira, Helal and Paiva (2016) demonstrated how the artisans acquired their skills and tacit knowledge within the community (in that case, their families), daily life, and practice. Moreover, the ability to make craftwork was not restricted to mastering the technique, but depended mainly on social meanings shared and associated with their identity and the construction of their place in the social space. 
Carrieri, Pereira and Correia (2018) and Alves, Farias and Pereira (2018) analyzed popcorn street vendors also in the municipality of Alcaçuz, focusing on their activities in the territory. The authors demonstrated the importance of mutual monitoring among the vendors themselves, in order to occupy and use the public space, contrasting the commercialization and the determination of places and borders, in addition to the search for power and positions, either through representativeness and associations or through negotiations with third parties (particularly public authorities).

Zioli, Rodrigues, Gaffuri and Ichikawa (2018) observe that daily practices not only compete to reproduce the social space, its places, and positions but create ruptures and allow divergent territorialization. In the case presented here, the daily practices are a strategic procedure of the social movement that intends, step by step, to achieve a place and a position - albeit uncertain in the face of the reactions of the status quo. It is about resilience and resistance, combined with change and no-change.

Resistance is a practice that occurs in everyday life, in the very modes of existence in the common social space, and in the ways of making use of such space (Vasconcelos \& Domingues, 2018).

For Haesbaert (2015), territorialization is the appropriation of space in which three dimensions stand out, not necessarily with equal importance: a) political; b) symbolic; and c) economic. It has a relational and temporal nature as it results from social processes in material space.

Saquet (2015) understands territorialization as space and time in movement: social relations produce territory in temporalities. Different sets of social relations and temporalities converge, overlap, and compete for space, characterizing multiple aspects of the dynamics of territorialization.

Mendes and Cavedon $(2013,2014,2015)$ and Mendes (2011) stress the cultural and economic dimensions of the general and informal commerce, whose temporality and territorialization provide survival and social integration to intermediaries and street vendors, and slowly, through successive installations over the months, a place (physical, economic, and symbolic) in the local social space. Territorialization is the action over time and space; it is a social construction, with symbolic and political dimensions, in multiple itineraries, encounters and disagreements, experiences.

In a report on movements of territorialization and deterritorialization, Pereira and Carrieri (2005) concluded that the symbolic space, territoriality, and deterritorialization are close to the concepts of organizations, practices, identity, cultural meanings, and power relations. In symbolic spaces such as the territory, there are ambiguity and relational aspects that allow us to enter the cultural traits.

The central question is not limited to learning a particular craft, to become a reproducer of practice, but involves how the learner can become a practitioner, develop an identity in this universe of spatially and temporally determined activities (Brown \& Duguid, 1991).

\section{METHODOLOGY}

The research used interviews, dialogue, and observation of ways of doing, documents, and artifacts. The study focused on the experience of a group of female artisans, describing and following their activities and practices. Also, the work seeks to identify the group's activities and practices temporally and spatially, the conditions of its existence, and discovering the meanings and relationships around the practices. The researchers visited the craft fair to observe, describe, and map the geography of the urban space and the immediate neighborhood. Other places and times of the artisans' activities were also visited (Gherardi, 2012; Nicolini, 2013; Stoddard, 2010; Van-Maanen, 2009; Van-Maanen \& Barley, 1982; Van-Maanen \& Kolb, 1982; Van-Manen, 2007).

The interviews allowed to approach, map, and understand the respondents' lives, through their respective narratives, which brings beliefs, values, attitudes, and motivations in a specific context (Bauer \& Gaskell, 2002).

The life story technique was adopted for the narrative interviews, with words and meanings specific to the artisans' experience and way of life. According to this technique, the interviewee can tell their story in a particular place and time, and the personal experiences shared to form a plot (Bauer \& Gaskell, 2002; Josselson, 2011; Webster \& Mertova, 2007).

Box 1 illustrates the procedure adopted in the narrative interview used in this study. 
Box 1

Basic phases of the narrative interview

\begin{tabular}{|l|l|}
\hline \multicolumn{1}{|c|}{ Phases } & \multicolumn{1}{c|}{ Rules } \\
\hline 1. Preparation & $\begin{array}{l}\text { Exploring the field } \\
\text { Formulating exmanent questions }\end{array}$ \\
\hline 2. Initiation & Formulating initial topic for narration Emprego de Using visual aids \\
\hline 3. Main narration & $\begin{array}{l}\text { No interruptions } \\
\text { Only non-verbal encouragement to continue story-telling } \\
\text { Wait for the coda }\end{array}$ \\
\hline 4. Questioning phase & $\begin{array}{l}\text { Only 'What happened then?' } \\
\text { No opinion and attitude questions } \\
\text { No arguing on contradictions } \\
\text { No why-questions } \\
\text { Exmanent into immanent questions }\end{array}$ \\
\hline 5. Concluding talk & $\begin{array}{l}\text { Stop recording } \\
\text { Why-questions allowed } \\
\text { Memory protocol immediately after the interview }\end{array}$ \\
\hline
\end{tabular}

Source: Jovchelovitch and Bauer (2002).

There are three procedures for analyzing the trajectories collected during the narrative interview: a) thematic analysis (conversion of data through the transcription of recorded interviews); b) Schultze's (2010) six-step proposal (first, the detailed transcription of verbal material; second, the differentiation between indexical and non-indexical material; third, the use of indexical material to order events; fourth, the non-indexical dimensions of the text are investigated as knowledge analysis opinions and reflections; fifth, the grouping and comparison of individual trajectories; and sixth, the identification of collective trajectories); and c) structuralist analysis (formal elements of the narrative) (Jovchelovitch \& Bauer, 2002).

Other instruments were also used in the field research, such as participant observation and document analysis.

Box 2

Description of research procedures

\begin{tabular}{|l|l|}
\hline $\begin{array}{l}\text { Number of hours } \\
\text { (Event, observation in the field, } \\
\text { participation in meetings) }\end{array}$ & 70 hours \\
\hline Number of interviews & 15 \\
\hline Analyzed Documents & $\begin{array}{l}\text { Municipal Law 14,786, February 23, 2016, Curitiba } \\
\text { (state of Paraná - PR, Brazil) } \\
\text { Regimento da Feira Economia Solidária do Portão } \\
\text { (Regiment of the Solidarity Economy Fair of Portão) }\end{array}$ \\
\hline Observation and participation & $\begin{array}{l}\text { Fair meeting at Tecsol - Solidarity Economy Incubator } \\
\text { of the Federal Technological University of Paraná } \\
\text { (UTFPR), Curitiba, PR } \\
\text { Assembly and disassembly of the craft fair } \\
\text { Solidarity Economy Exhibition at UTFPR }\end{array}$ \\
\hline Collected Material & $\begin{array}{l}\text { Photos } \\
\text { Folders }\end{array}$ \\
\hline
\end{tabular}

Source: Elaborated by the authors. 
The artisans were identified by the initial letters of their names: A.M., E.D.1; E.D. 2; M.A. 1; M.A. 2; AT.; PAN.; S.I. (see Box 3 below).

Each interview was transcribed and allocated a number in the data set sequence. The excerpts of the interviews presented in this article contain the number that identifies them with the lines of the transcribed text. For example, 11, 2-3 - interview number 1, lines 2 and 3; I10, 12-14 - interview number 10, lines 12 to 14 .

The researchers worked in immersion for approximately six months (July to December). Observation and participation took place during the artisans' work meetings, accompanying them in their commute, their research and production projects, and whole days at the craft fair (from before the assembly of the infrastructure until the end of the day, the disassembly and storage of equipment and products). The field notes were kept in a diary, used as a source to describe the elements of the case. The dialogues and interviews were transcribed and qualitatively analyzed through content analysis possible. This analysis supported the identification of themes and contents of the group's and the enterprise's experiences.

\section{DATA PRESENTATION AND DISCUSSION}

\section{General description of activities: location, positioning, and territorialization}

The women arrive early to set up the stalls. As they arrive, they concentrate on the space for assembling the stalls and wait for the parking lot to open to pick up the structures to set up the stalls, chairs, tables, plastic tarpaulins, stall protection, and portable stalls. This activity is divided into tasks, according to the physical and health possibilities of the artisans. Some are unable to carry weight, so they prepare and pack the goods, which will be exhibited at the fair.

Everyone assembles the stall structures. Only after the structures are ready, the artisans start to organize each stall - at least three artisans per stall. At that moment, each artisan arranges their own space, checking the layout of products, the visibility of prices, the display of new products, the production of posters. Each vendor organizes their space in their way.

\section{[...] Everyone assembles and dismantles the stalls together (12, 2-3).}

The artisans still do not have all legal documentation to operate, which is a challenge for them. They are aware of the situation and work together to overcome the problem. Every day at the fair, the artisans cannot avoid the fact that they have to struggle with the difference marked by the conception of the solidarity economy in comparison to the massive commercial activity of the neighboring shopping malls, in addition to dealing with passersby's ignorance regarding the popular economy.

[...] A client comes and asks for a soda, then we have to explain that this is a solidarity economy craft fair, we don't work with brands, we produce everything ourselves $(13,5-6)$.

[...] We are winners, almost two years ago, we are the leading actors in our own space (17, 3-4).

[...] We have grown, we got an accountant, information, papers, and [we are] almost finalizing the legalization of our fair (15, 10-11; 19, 7-9).

The daily observations of the event and the interviewees' testimonies converge to demonstrate that, for the artisans, the enterprise is a mission and a way to position themselves in society proactively. These are descriptive elements of their sense of existence, which they recognize has been built, understood, and made real in their lives in the day-to-day clashes, to guarantee their survival, among themselves and with passersby, in order to overcome indifference.

[...] I tell the story of my own product, seek innovation, and ask friends who travel to bring me different seeds [raw material] for my craftwork (I3, 13-14). 
The artisans are determined to set up the craft fair twice a week continuously, and for the entire day, come rain or shine. They are always attentive to the situation of their peers and ready to assist when necessary. They also show a kind and welcoming attitude toward visitors, who are not seen as potential buyers, but as their "students" or "children," with whom they share what they consider to be their most precious gift.

\section{[...] A 9-year-old girl came and said she had a school project to complete, so I told her the story behind} the wall hangings I produce. She got the highest grade $(13,16-17)$.

Most artisans are between 55 and 60 years old, with an average age of 53. Only 30\% are newcomers. Most have been at the craft fair for over two years. In other words, they are mature women who undertake solidarity enterprise and exchange experiences with the younger ones, who gather and mobilize the crat fair participants for meetings, sharing experiences of life and solidarity economy.

[...] We have a regiment with the principle of solidarity economy and the craft fair (15, 6-7).

[...] I help in the administration; I do the cash-book. To raise funds, we hold bazaars and exchange clubs $(I 1,9-10)$.

[...] Every Wednesday, before the fair opens to the public, we have coffee and say a prayer, to start our day well $(11,4-5)$.

\section{The craft fair as an element of 'organizing,' a complex set of coordinated activities}

As a practice, the craft fair is not limited to the moment when it is set up in the public space, with the stalls and the exhibition and marketing activities. The fair demands a series of other precedent and following activities, all necessary and contributing to the success and quality of the event.

[...] Everyone at the fair has to make their products. This is the rule of the solidarity economy. If I don't have products, my group will help me so I can work. Each artisan represents an enterprise of at least three people $(113,3-5)$.

The fair's work extends to different times and places, in addition to requiring huge dedication from the artisans. This concerns purchases of raw materials, preparation and processing of products, research, and study of materials and techniques. This research identified and mapped the extent of these activities and the conditions of the artisans to manage them. They coordinate and lead the processes as an action group, with purpose and dynamic capabilities. In this regard, according to Gropp and Tavares (2007), the following aspects stand out:

- The division of time and temporalities occurs in two ways: direct - in the moments they are together - and indirect concerning the projects and activities carried out in moments and places other than the fair;

- There are different specialized knowledge to help the enterprises to thrive and to carry out the activities of selling, setting up the stalls, managing the fair as an event, and planning the collective activities;

- In addition to their sense of existence, the social situation and identity found in associative self-management are the elements that distinguish them from others. Through this associative dynamic, the artisans work together to set up the craft fair, contribute to a collective fund when there is commercialization. The dynamic is present in the way of conducting the meetings, setting the agenda, open spaces for opinions, and vote in decision-making processes.

It is also noteworthy that there are competing temporalities related to various activities, such as those of research, design, preparation of production conditions, and production itself. These times depend on the craft technique's characteristics, the product, and the artisans' profile and working conditions. In addition, there is time for personal preparation of the craft fair participant, their displacement, organizing the stall, and the permanence in the public space.

Box 3 correlates the activities that involve the practice with the places (spaces) and times available for that purpose. 
Box 3

Fairs and activities

\begin{tabular}{|c|c|c|c|c|c|c|c|}
\hline Fair & Monday & Tuesday & Wednesday & Thursday & Friday & Saturday & Sunday \\
\hline $\begin{array}{l}\text { Artisan } \\
\text { N. A. }\end{array}$ & $\begin{array}{l}\text { R. F. ECOSOL- } \\
4 \text { hours } \\
\text { R. F. } 4 \text { hours }\end{array}$ & P- 7 hours & $\begin{array}{l}\text { F- } 9 \text { hours } \\
\text { P- } 5 \text { hours }\end{array}$ & $\begin{array}{l}\text { P- } 7 \text { hours } \\
\text { P. I- } 2 \text { hours } \\
\text { T. E. A. P- } 2 \text { hours }\end{array}$ & $\begin{array}{l}\text { P- } 5 \text { hours } \\
\text { C. M.- } 3 \text { hours }\end{array}$ & $\begin{array}{l}\text { F- } 9 \text { hours } \\
\text { P- } 5 \text { hours }\end{array}$ & P- 7 hours \\
\hline $\begin{array}{l}\text { Artisan } \\
\text { P. A. }\end{array}$ & $\begin{array}{l}\text { R. F. ECOSOL- } \\
4 \text { hours } \\
\text { R. F. }-4 \text { hours; } \\
\text { C. M.- } 2 \text { hours }\end{array}$ & $\begin{array}{l}\text { P. } 1-2 \text { hours } \\
\text { P- } 6 \text { hours }\end{array}$ & F- 9 hours & P- 6 hours & P- 6 hours & P- 6 hours & P- 6 hours \\
\hline $\begin{array}{l}\text { Artisan } \\
\text { M. A. } 1\end{array}$ & $\begin{array}{l}\text { R. F. ECOSOL- } \\
4 \text { hours } \\
\text { R. F. }-4 \text { hours } \\
\text { C. M. }-2 \text { hours }\end{array}$ & $\begin{array}{l}\text { P- } 5 \text { hours } \\
\text { C. M.- } 2 \\
\text { hours }\end{array}$ & F-9 hours & $\begin{array}{l}\text { P- } 5 \text { hours } \\
\text { P. I- } 3 \text { hours }\end{array}$ & P- 5 hours & P- 5 hours & P- 5 hours \\
\hline $\begin{array}{l}\text { Artisan } \\
\text { M. A. } 2\end{array}$ & $\begin{array}{l}\text { R. F. ECOSOL- } \\
4 \text { hours } \\
\text { R. F. } 4 \text { hours } \\
\text { C. M. - } 2 \text { hours }\end{array}$ & P- 5 hours & F-9 hours & $\begin{array}{l}\text { P. } 5 \text { hours } \\
\text { R. G. P.- } 3 \text { hours }\end{array}$ & P- 5 hours & F-9 hours & $\begin{array}{l}\text { P. M. P.- } 4 \text { hours } \\
\text { [G. P. C. - } 4 \text { hours, } \\
\text { once a month] }\end{array}$ \\
\hline $\begin{array}{l}\text { Artisan } \\
\text { S. I }\end{array}$ & $\begin{array}{l}\text { R. F. ECOSOL- } \\
4 \text { hours } \\
\text { R. F. } 4 \text { hours; } \\
\text { C. M. }-3 \text { hours }\end{array}$ & P- 4 hours & F-9 hours & C. M.- 3 hours & P- 4 hours & F-9 hours & $\begin{array}{l}\text { C. F. F.- } 2 \text { hours } \\
\text { C. F. Fs.- } 1 \text { hour }\end{array}$ \\
\hline $\begin{array}{l}\text { Artisan } \\
\text { E. D. } 2\end{array}$ & $\begin{array}{l}\text { R. F. ECOSOL- } \\
4 \text { hours } \\
\text { R. F. } 4 \text { hours; } \\
\text { C. M.- } 2 \text { hours }\end{array}$ & $\begin{array}{l}\text { P. M. P.- } \\
4 \text { hours } \\
\text { P- } 6 \text { hours } \\
\text { P. I- } 1 \text { hour }\end{array}$ & $\begin{array}{l}\text { P. M. P.- } \\
4 \text { hours } \\
\text { P- } 6 \text { hours } \\
\text { P. I- } 1 \text { hour }\end{array}$ & P- 10 hours & P- 10 hours & F- 9 hours & P- 5 hours \\
\hline $\begin{array}{l}\text { Artisan } \\
\text { A. M. }\end{array}$ & $\begin{array}{l}\text { R. F. ECOSOL- } \\
4 \text { hours } \\
\text { R. F. } 4 \text { hours }\end{array}$ & P- 5 hours & $\begin{array}{l}\text { P- } 5 \text { hours } \\
\text { R. G. P.- } \\
3 \text { hours }\end{array}$ & P- 5 hours & C. M.- 3 hours & $\begin{array}{l}\text { F- } 9 \text { hours } \\
\text { P. I. R.- } 1 \text { hour }\end{array}$ & P. I- 1 hour \\
\hline $\begin{array}{l}\text { Artisan } \\
\text { E. D. } 1\end{array}$ & $\begin{array}{l}\text { R. F. ECOSOL- } \\
4 \text { hours } \\
\text { R. F. }-4 \text { hours } \\
\text { P. } 3 \text { hours }\end{array}$ & $\begin{array}{l}\text { C. M.- } \\
3 \text { hours } \\
\text { P- } 5 \text { hours }\end{array}$ & F- 8 hours & P- 5 hours & P- 5 hours & F- 9 hours & \\
\hline
\end{tabular}

Key:

C. F. F. - Financial control of the fair

C. F. Fs. - Control of artisans' frequency

C. M. - Purchase of merchandise, prime-material

F- Fair

G. P. C. - Group produce collectively

$\mathrm{P}$ - Production

P. I. - Research to innovate the products on the internet

P. I. R. - Research of innovation in journals/magazines

P. M. P. - Prepare material to produce

R. F. ECOSOL - Meeting of the Forum of Solidarity Economy

R. F. - Fair meeting

R. G. P. - Meeting of the production team

T. E. - Exchange of craft and product experiences

Source: Elaborated by the authors. 
It is demonstrated that the majority of artisans worked daily with activities linked to the fair, whether through production, participation in meetings, researching product innovations, purchasing materials, training, and events in universities, as required. On average, they dedicate 36 hours/week to the fair. Given the above, it appears that there is not only the time for the fair itself but a conjunction of correlated activities, which extend to other environments, with several hours not related to the activity during the sales at the craft fair.

The artisans produce daily to have a variety of products and increase sales since the fair is not attractive to customers if there are only a few products. Customers always seek a variety of options that include colors, models, sizes, and formats.

[...] I launched a baby changing bag with a mat, baby wipes, and cream. I'm starting a line of football and gym bags $(14,6-7)$.

[...] A client arrives and asks for a specific design, then they send the design via WhatsApp, and I embroider the design in the product. I have a new towel embroidered for 'Festa Junina' [traditional Brazilian party that happens in June] $(18,12-13)$.

[...] Sometimes, there is a lack of money to buy material. Then we have to find substitute material, we discuss and research $(15,9-10)$.

The period of resting also involves activities related to the fair, either researching materials or techniques on the internet, or traveling and working while on the way, and when they are on the beach, they also produce (a moment the artisans consider therapeutic).

There is no set calendar for the production of festivities; each stall and its group decided what they will produce, but that does not stop them from observing the commercial calendar.

\section{RESULTS AND ANALYSIS}

These artisans work individually and collectively in this craft fair. They are, at the same time, 'employers' and 'employees,' conducting the activities in the process of self-management, and showing solidarity with each other and attention to their customers. The research revealed the artisans' weekly challenge of having to work for five days in order to carry out two full days of craft fair (Wednesday and Saturday) and, simultaneously, having to take care of their families.

The craft fair does not happen automatically, nor is it facilitated based on the repetition of the same procedures. The existence of such endeavor flows dynamically, because, in addition to cultivating the attitude of seeking innovation, the artisans have to deal with unforeseen situations and the competition (from other products, ideas, and communication strategies that attract the consumers' attention). Therefore, there are internal and external elements leading to the group's learning. It is worth mentioning that the group is stable, and new members enter only after a careful admission process conducted by the artisans. Different forms of participation - in planning, producing, or commercialization, for instance - may describe the learning process, which is marked by the mutuality observed in the flow of the parallel and joint activities. The artisans form a community of practice, as they are engaged, develop, and maintain an enterprise daily, which reconstructs a shared repertoire (constituted from a group experience, but inspired by the popular economy). They delineate the rules that guide the enterprise's operation and the decision-making process, and the production occurs collectively according to each of the artisans' initiative.

In this sense, 'belonging' and 'differentiation' are important elements. There is something that happens when they are together, in terms of learning, knowledge, and structuring of actions. There is companionship among them, translated into gestures, attitudes, and actions such as taking care of each other's stall, recommending a peer to a customer looking for a specific product, or even talking to a colleague that seems very quiet. All of these gestures denote ties that strengthen affective relationships and friendship.

However, there are rules of coexistence and a strong feeling of a collective commitment. Even though each artisan and each stall represent a small enterprise, the craft fair as a whole constitutes a more significant endeavor engaging and uniting the group. 
The artisans have a unique way of selling their products, based on their historical and cultural context. This element is another that differentiates the craft fair from other businesses.

They self-identify as practitioners of the solidarity economy.

When transposing the craft fair to the symbolic space, it appears to encompass other concepts, such as a) the activities carried out to constitute the practice; b) the identity the artisans adopt when saying "we are a fair of solidarity economy;" c) the relational aspects they develop with those who are directly and indirectly connected with the fair; and d) the power relationships that they must put into practice when in contact with the public, from the legal aspects to market systems, in addition to the artisan's interaction with each other through the established rules.

The concept of the territory allows understanding the history of the social actors as part of an organization. As the craft fair is considered as something so precious, it somehow contributes to the artisans' mental and physical health. This aspect shows the identification processes and the registration of the person's history within the organization.

Territorialization is part of the community and the learning process. The relationship the artisans develop with third parties, such as police officers, students, passersby, and homeless people, extends and involves the other characters in the craft fair's territorialization. Some of the artisans say that customers visiting the fair discuss fashion trends, suggest products, and exchange experiences.

However, the observations and content of the artisans' reports confirm and recognize the power and influence of being a neighbor of shopping malls. These elements define a specific spatial and social organization that creates a reality and imposes a socialization process for its users, as suggested by Lengler and Cavedon (2018). Despite being private spaces created for the community, two malls close to the craft fair have reconfigured the public space and the neighborhood in symbolic, economic, and political terms. In addition, these shopping malls changed the very behavior of those who transit or live in the region. For example, the fact that they are immense buildings required small businesses to be more distant from the malls in order to gain more visibility (a measure that was not considered necessary in the case of nearby commercial galleries).

However, the presence of these massive players did not intimidate the artisans, who had to recognize them and develop skills to establish conviviality with the neighbors. The occupation of space is not only material, but also symbolic, and phenomenological. Territorialization occurs in the form of occupation and disposition of the fair (its positioning in the public social space). The economic, political, cultural, and symbolic dimensions are intertwined. The fair does not violate the order defined in that place but creates an enclave, and it is inserted in the social space. Each day of the fair, artisans need to physically reconstruct the symbolic space, starting to exist in that place and assuming a position in front of others, especially their neighbors.

This reality differs from the traditional view of 'community of practice,' located in a pre-existing space, or situated in a context and social structure from which derives its matrix or foundation. In the case studied, it is possible to observe the opposite. This community must have, among the activities of its practice, those dedicated to bringing its locus, its space, its territory into existence, competing, or facing the dominant conditions in the social space. Here, the concepts of territory - planned, negotiated, lived - may be differentiated.

\section{MAIN FINDINGS}

The craft fair is a collective enterprise, and its core activity is the event that represents a place for a location where the artisans exhibit and commercialize their products.

The fair represents space and time of joint knowledge, a community context, and an environment of identity - the solidarity economy system - for those who form the event.

There are elements to analyze the group of artisans as a community of practice, and their collective entrepreneurial action as a practice from the perspective of social learning theory.

These artisans are a community of practice since they share a set of problems and interact with each other on an ongoing basis, creating products, and developing a tacit understanding. Such a community is not restricted to the moment and space of the event 'craft fair.' The enterprise is embodied in the collection of activities happening in several times and places. 
It represents the collective construction of these women. Their coexistence and experience are elements that host and nurture a culture not restricted to the fair, reaching their families and homes.

This phenomenon is also immaterial, due to the way the activities are organized, their coordination, direction, intertwining. There is no manual that artisans consult for guidance on their actions and existence. Nor is there a constituted place for them to play their roles. The case suggests that, as an organization, there is more action than structure. It is possible to observe the existence of rules, although fewer than the ones of organizations in general, and almost all of them unwritten. Still regarding this immateriality, stands out the expansion of the enterprise's activities such as a) the strategy of collectively purchasing raw material; b) research on how to innovate the product; c) search for suppliers; d) production; e) participation in the fair's meetings; f) activities of the fair's incubator; and g) participation in training sessions about solidarity economy. All these activities converging to the practice called here 'craft fair.'

The artisans somehow face the confrontation of power. This aspect does not refer only to fulfilling the legal requirements regarding documents and regulations, but under the economic and cultural perspectives (the dominance of the current consumerism and capitalist system) and also under the spatial perspective, with the two large neighboring malls.

However, the artisans won a place. For the local community and the neighborhood, the craft fair is part of the landscape and is embedded in the pace of local events. There are customers who, before going to work, stop by the food stall to buy snacks or to visit the other stalls. Other actors pass by the fair, such as street vendors, city inspectors, homeless people, police officers, students, and employees of the neighborhood's cultural center. The artisans end up developing a relationship with these actors. They approach and try, as far as possible, to help them when, for example, a) they give coffee and bread to homeless people; and b) they make baskets with their products to celebrate festivities, particularly Easter and Christmas, offering them to employees of the neighborhood cultural center, as a way of thanking them for socializing throughout the year. The group is receptive to students or anyone who wants to know something about solidarity economy and the craft fair. In the community of practice, there is temporalization and a calendar for production that precedes commercialization and territorialization.

In the artisans' point of view, according to what was observed and achieved in the various strategies adopted in this research, the relationship they established in the territorialization combine symbolic distances and possibilities of interaction. Figure 2 represents these elements as a circular gradient of positions in the configuration of this territory.

Figure 2

Circular gradient of territorialization as a group practice, interactions, and positioning

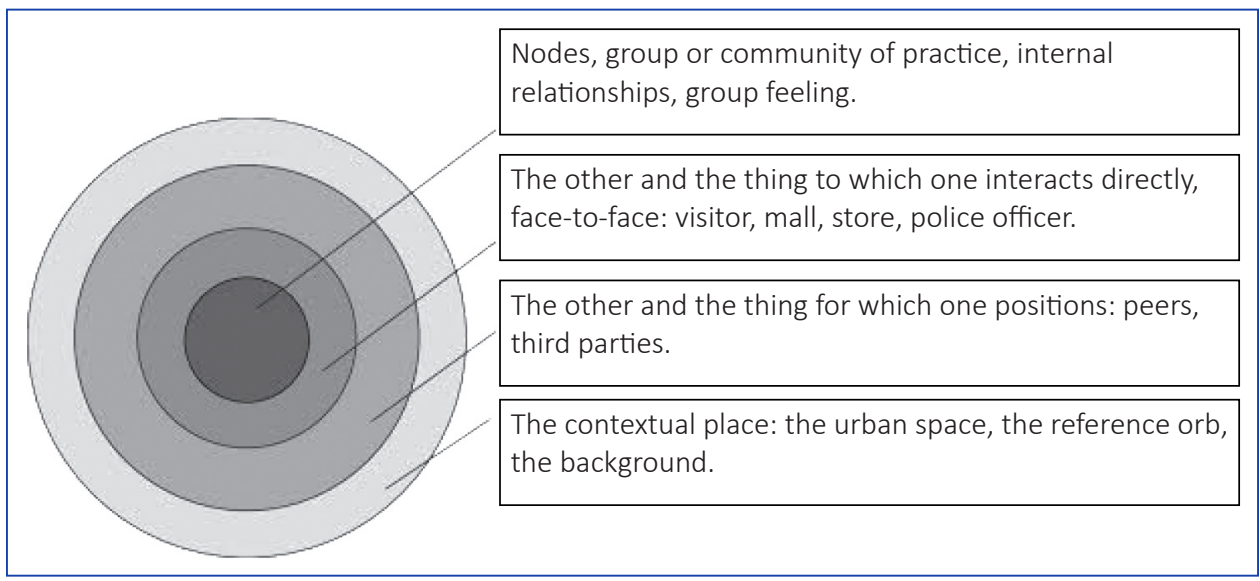

Source: Elaborated by the authors.

The artisans take ownership of the public space, build, symbolize, attribute meaning, and engage third parties who pass by. They manage to shape their own space, so they have a pace, a proposal, a symbolic value, which is essentially the combination of the craftwork and solidarity economy. They organize actions and activities, establish their pace and times. 
Observation and analysis enabled the identification of the following experiences and configurations of space and time, which end up designing the form of participation:

1. The time and space for transportation;

2. The time and space to set up;

3. The space and time of the event;

4. The time and space of support and the public event;

5. The space and time of the community meeting and practice;

6. The time and space for reflection and consolidation of knowledge;

7. The time and space of the fair visitor (kairós); and

8. The time and space of production.

The activities focused on territorialization are a fundamental part of the practice for this type of enterprise. They imply learning according to the model proposed by the social theory of group or community practice. Table 4 synthesizes these data and conclusions, considering as a starting point, the main axes of the social theory of practice, as proposed by Wenger (2011, pp. 20-30).

Box 4

Elements of territorialization as practice and learning

\begin{tabular}{|c|c|c|c|c|}
\hline $\begin{array}{c}\text { Main axes of the } \\
\text { social theory }\end{array}$ & $\begin{array}{l}\text { Implication for } \\
\text { community } \\
\text { learning }\end{array}$ & $\begin{array}{c}\text { Territorialization } \\
\text { content }\end{array}$ & $\begin{array}{l}\text { Meanings based } \\
\text { on analyzed data }\end{array}$ & $\begin{array}{l}\text { Examples: mentions } \\
\text { and parts of interviews }\end{array}$ \\
\hline Community & $\begin{array}{l}\text { - Affiliation } \\
\text { - Social structure }\end{array}$ & $\begin{array}{l}\text { Position } \\
\text { (economic, political, symbolic, } \\
\text { cultural) in relationship with: } \\
\text { - others } \\
\text { - peers } \\
\text { - context }\end{array}$ & $\begin{array}{l}\text { - Relationship with } \\
\text { - Interact with } \\
\text { - Be an entrepreneur }\end{array}$ & $\begin{array}{l}\text { "you are the meaning of } \\
\text { our existence, our work, our } \\
\text { enterprise." }\end{array}$ \\
\hline Practice & $\begin{array}{l}\text { - How to do } \\
\text { - Coordinating } \\
\text { spaces and times }\end{array}$ & $\begin{array}{l}\text { - Dynamic capacity of } \\
\text { self-management and of managing } \\
\text { interactions } \\
\text { (also implies learning) } \\
\text { - Boundaries }\end{array}$ & $\begin{array}{l}\text { - Build } \\
\text { - Negotiate } \\
\text { - Occupy } \\
\text { - Confront } \\
\text { - Seduce } \\
\text { - Coopt } \\
\text { - Contract } \\
\text { - Set up the fair } \\
\text { - Produce the craftwork } \\
\text { - Act artistically }\end{array}$ & $\begin{array}{l}\text { "They realize that we are } \\
\text { simple people with no } \\
\text { resources." } \\
\text { "Each of us makes their own } \\
\text { craftwork, but everything } \\
\text { here is planned collectively } \\
\text { every detail." }\end{array}$ \\
\hline Meaning & - Experience & $\begin{array}{l}\text { - Meaning of work } \\
\text { - Contrast with the social structure } \\
\text { and space } \\
\text { - Ideals } \\
\text { - Living and learning in a group }\end{array}$ & $\begin{array}{l}\text { - Explain - to yourself } \\
\text { and others - what is it } \\
\text { you do, why you do, and } \\
\text { what is it for. } \\
\text { - Understand the others } \\
\text { - Perceive the differences }\end{array}$ & $\begin{array}{l}\text { "This is our work, my } \\
\text { friend. It is the popular and } \\
\text { solidarity economy!" } \\
\text { "I live and offer these people } \\
\text { a new form of living, a new } \\
\text { economy." }\end{array}$ \\
\hline Identity & $\begin{array}{l}\text { - Becoming } \\
\text { - Process } \\
\text { - Flow }\end{array}$ & $\begin{array}{l}\text { - Sense that the group is a subject } \\
\text { and content, with increasing } \\
\text { ownership of the situation } \\
\text { - Group members understood as } \\
\text { subjects with increasing ownership } \\
\text { of the situation. }\end{array}$ & $\begin{array}{l}\text { - Identify and overcome } \\
\text { problems } \\
\text { - Define who we are and } \\
\text { our place }\end{array}$ & $\begin{array}{l}\text { "We manage to sort out our } \\
\text { challenges. We kill a lion } \\
\text { every day and week!" }\end{array}$ \\
\hline
\end{tabular}

Source: Elaborated by the authors. 
When connecting the case to the concepts presented in the theoretical framework presented in a previous section of this article, it is possible to argue that territorialization does not mean only the creation of a physical space or a place in that part of the neighborhood. The territorialization is not completed in the group's positioning in the local geography and in that landscape dominated by two large shopping malls.

Territorialization is an essential element in the reconstruction of the artisans' identities and learning process. The weekly construction of the craft fair is the materialization of the scenery and dramatization, the participation and experience of cultural elements, and their feelings and meanings. In this set of actions, understood as a practice, roles and identities are always being reconstructed and reconfirmed. There is a vital link between territorialization and identities because the following aspects have been defined through participation: a) the negotiated experience of who they are as a group and as social agents, what they are doing there, and what for; $b$ ) the artisans' learning trajectory, c) their commitments and responsibilities, and d) their affiliations. The phenomenon is the result of the awareness and knowledge exercised in daily life, referring to the way the territorialization and the identities become real as part of "us" (a group) - in the face of the others and become a 'thing' also referring to the way they are gathered, represent, and communicate their history and their connections and affiliations (cultural and symbolic elements). Finally, territorialization and identities refer to the way the artisans cultivate their political existence, through acts of choice, purpose, positioning, negotiation, and the future.

Identity is not explained only by the occupational nature of the group's work, as they are artisans. Observations and data point out that identity is closely linked to values and the meanings attributed to their knowledge, as well as to the women's interpretations of popular and solidarity economy. All these aspects are related to the fact that they are in that specific territory, in that community. The artisans could be faced as co-operators or spectators.

This symbolic element of the craftwork corresponds to the artisans' interpretations and constitutes political acts. The artisans are aware that others compete in the social space, with divergent values regarding individual production, different concepts of what is a handmade product.

However, the craftwork and the organization of the craft fair are part of the artisans' trajectory of reflection, experience, and learning. Through these activities of production and territorialization, the artisans learn and negotiate social and cultural meanings, exercise their differences at the same time as maintaining their group identity.

\section{FINAL CONSIDERATIONS}

This study explored how the mapping of spatial-temporal elements, based on a perspective of situated learning, offers new insights about group enterprise as a practice, and about the knowledge shared among and through organizational communities. The research also contributes to understanding the processes of building identities and power relations inherent in forms of group participation and learning.

The study assumes that space and time constitute social practices, and are constituted by social practices and relationships. The way the group (community) is positioned in the social space and interacts with the elements and external agents to build its locus is composed of a set of activities that dialog with the practice's social and historical context. These activities constitute a practice of positioning and territorialization in the social space (which is different from the perspective that the context unilaterally facilitates and hinders learning and sharing).

The ability to build the space-time order is a form of social power. In this case, it proved to be a challenge for the group's enterprise, and for the content of situated and community learning.

It is difficult for artisans to modify the spatial and temporal conditions of their work, but these conditions characterize limitations and opportunities for group learning. The face-to-face meetings that take place at the craft fair, for example, facilitate visualizing the group work, whereas the artisans work at home reflects a group activity of production, carried out at a distance. 
The craft fair continues to be the main time and place where the artisans maintain and reinforce their identities (at the individual and collective level), the sense of belonging to their group (community), and where they master their practice while sharing a meaning for the joint activities.

The set of group activities and the notion of 'organizing' observed in practice demonstrates how space and time influence the modes of participation and present essential elements of the women's learning and domain of their enterprise and relationships.

Finally, this article sought to clarify the possibility of dialogue between the concepts of 'community of practice' and entrepreneurial group action, and the concepts of social space and territorialization. Further studies may explore in-depth the spatial-temporal conditions of such phenomena and the implications of these concepts for learning.

\section{ACKNOWLEDGMENTS}

We thank the support from the Universidade Positivo, for the scholarship of the National Postdoctoral Program / CAPES PNPD according the Edital No. 005/2016 - PMDA. 


\section{REFERENCES}

Alves, C., Farias, G., \& Pereira, H. G. (2018). Cotidiano e identificação: o ser trabalhador pipoqueiro belo-horizontino. In Anais do 42ㅇ Encontro da Associação Nacional dos Programas de Pós-Graduação em Administração, Maringá, PR.

Bachelard, G. (1978). A filosofia do não; Novo espírito científico: a poética do espaço (Coleção Os Pensadores). São Paulo, SP: Abril Cultural.

Bourdieu, P. (1997). Efeitos do lugar. In P. Bourdieu (Org.), Miséria do mundo (pp. 159-166). Petrópolis, RJ: Vozes.

Bourdieu, P. (2013). Espaço físico, espaço social e espaço físico apropriado. Estudos Avançados, 27(79), 133-144.

Brown, J. S., \& Duguid, P. (1991). Organizational learning and communities of practice: toward a unified view of working, learning, and innovation. Organization Science, 2(1), 40-57.

Carrieri, A., Pereira, H. G., \& Correia, G. F. A. (2018). A pipoca e seu território nos arranjos organizativos de trabalhadores ambulantes belo-horizontinos. In Anais do 42 Encontro da Associação Nacional dos Programas de Pós-Graduação em Administração, Maringá, PR.

Certeau, M. (2014). A invenção do cotidiano. Petrópolis, RJ: Vozes.

Chiesa, C. D., Gois, P. H., De Luca, G. \& Cavedon, N. R. (2015). Tramando arames, pedras e fios: espaço e estigma no trabalho de um artista. Ciências Sociais Unisinos, 51(1), 32-41.

Davel, E., Cavedon, N. R., \& Fischer, T. (2012). A vitalidade artesanal da gestão contemporânea. Revista Interdisciplinar de Gestão Social, 1(3), 11-19.

Fahy, K. M., Easterby-Smith, M., \& Lervik, J. E. (2014). The power of spatial and temporal orderings in organizational learning. Management Learning, 45(2), 123-144.

Ferrarini, N. L., Camargo, D., \& Bulgacov, Y. L. M. (2014). Comunidades de práticas sociais e o debate sobre a formação do psicólogo. International Journal of developmental and educational Psichology INFAD, 2(1), 299-306.

Ferreira, T. B., Helal, D. H., \& Paiva, K. C. M. (2016). Artesanato, aprendizagem social e comunidade de prática: um estudo com rendeiras em Alcaçuz (RN). Revista Brasileira de Gestão e Desenvolvimento Regional, 12(1), 33-61.

Gherardi, S. (2012). How to conduct a practice-based study: problems and methods. Cheltenham, UK: Edward Elgar.

Giddens, A. (1985). Time, space and regionalisation. In D. Gregory, \& J. Urry (Ed.), Social relations and spatial structures (critical human geography) (pp. 265-295). Basingstoke, UK: Palgrave.

Giddens, A. (2003). A constituição da sociedade. São Paulo, SP: Martins Fontes.

Gouvêa, M. T. A., Paranhos, C., \& Motta, C. L. R. (2008). Promovendo o aprendizado organizacional por meio das comunidades de prática. Boletim Técnico do Senac, 34(3), 49-62.

Gropp, B. M. C. (2005). Uma abordagem etnográfica em comunidades de prática (Masther Thesis). Pontifícia Universidade Católica de São Paulo, São Paulo, SP.
Gropp, B. M. C. (2007). De cascão a lagartixa: uma abordagem etnográfica de comunidades de prática em aprendizagem organizacional. In J. A. Valente, K. Mazzone, \& M. C. Baranauskas (Org.), Aprendizagem na era das tecnologias digitais (v. 30235, pp. 203-222). São Paulo, SP: Cortez.

Gropp, B. M. C., \& Tavares, M. G. P. (2007). Comunidade de prática: gestão de conhecimento nas empresas. São Paulo, SP: Trevisan.

Haesbaert, R. (2015). O mito da desterritorialização. Rio de Janeiro, RJ: Bertrand Brasil.

Hagerstrand, T. (1975). Space, time and human conditions. In A. Karlqvist, L. Lundqvist, \& F. Snickars (Eds.), Dynamic allocation of urban space (pp. 3-14). Lexington, MA: Lexington.

Harvey, D. (2017). Condição pós-moderna. São Paulo, SP: Loyola.

Humes, L. L., \& Reinhard, N. (2006). A adoção do software livre na Universidade de São Paulo. RAUSP Management Journal, 41(3), 14-39.

Josselson, R. (2011). Narrative research: constructing, deconstructing and reconstructing story. In F. J. Wertz, K. Charmaz, L. M. McMullen, R. Josselson, R. Anderson, \& E. McSpadden (Org.), Five ways of doing qualitative analysis (pp. 224-242). New York, NY: Guilford.

Jovchelovitch, S., \& Bauer, M. W. (2002). Entrevista narrativa. In M. W. Bauer, \& G. Gaskell (Eds.), Pesquisa qualitativa com texto, imagem e som: um manual prático (pp. 90-113). Petrópolis, RJ: Vozes.

Lave, J. (2011). Apprenticeship in critical ethnographic practice. Chicago, IL: University of Chicago Press.

Lave, J., \& Wenger, E. (1991). Situated learning: legitimate peripheral participation. Cambridge, UK: Cambridge University Press.

Lefebvre, H. (1974). La production de l'espace. Paris, France: Anthropos.

Lengler, J. F. B., \& Cavedon, N. R. (2018). Do "templo do consumo" à representação mitológica: um olhar etnográfico desconstrutivo sobre os ritos no shopping center. In Anais do 42을 Encontro da Associação Nacional dos Programas de Pós-Graduação em Administração, Maringá, PR.

Lervik, J. E., Fahy, K. M., \& Eastertby-Smith, M. (2010). Temporal dynamics of situated learning in organizations. Management Learning, 41(3), 285-301.

Mendes, L. (2011). As culturas organizacionais territorializadas na atividade de camelô em Três Lagoas (Doctoral Dissertation). Universidade Federal do Rio Grande do Sul, Porto Alegre, RS.

Mendes, L., \& Cavedon, N. R. (2013). As culturas organizacionais territorializadas. Revista de Ciências da Administração, 15(35), 108-123.

Mendes, L., \& Cavedon, N. R. (2014). O mercado de camelôs e as contribuições ao desenvolvimento local de uma cidade. Interações, 15(2), 341-352.

Mendes, L., \& Cavedon, N. R. (2015). Território como ordem e caos: relação de poder entre camelôs, poder público e comerciantes. BASE: Revista de Administração e Contabilidade da UNISINOS, 12(1), 15-26.

Mendes, L., \& Urbina, L. M. S. (2015). Análise sobre a produção acadêmica brasileira em comunidades de prática. Revista de Administração Contemporânea, 19(3), 305-327. 
Nicolini, D. (2013). Practice theory, work \& organization: an introduction. Oxford, UK: Oxford University Press.

Nicolini, D., Scarbrough, H., \& Gracheva, J. (2015). Communities of practice and situated learning in healthcare. In E. Ferlie, K. Montgomery, \& A. R. Pedersen (Ed.), Oxford handbook of health care management (pp. 255-278). Oxford, UK: Oxford University Press.

Pereira, D. C., \& Carrieri, A. P. (2005). Movimentos de desterritorialização e reterritorilização na transformação das organizações. Revista de Administração de Empresas, 4(1), 13-43.

Saquet, M. A. (2015). Abordagens e concepções de território. São Paulo, SP: Outras Expressões.

Schultze, F. (2010). Pesquisa biográfica e entrevista narrativa. In V. Weller, \& N. Pfaff (Org.), Metodologias da pesquisa qualitativa em educação: teoria e prática (pp. 211-222). Petrópolis, RJ: Vozes.

Stoddard, R. H. (2010). Field techniques and research methods in geography. Dubuque, IA: KendalUHunt.

Van-Maanen, J. (2009). A song for my supper: more tales of the field. Organizational Research Methods, 13(1), 240-255.

Van-Maanen, J., \& Barley, S. R. (1982). Occupational communities: culture and control in organizations. In B. Staw, \& L. Cummings (Ed.), Research in organizational behavior (v. 6, pp. 287-366). Greenwich, CT: JAI Press.

Van-Maanen, J., \& Kolb, D. (1982). The professional apprentice: observation on fieldwork roles in two organizational settings.
In S. B. Bacharach (Ed.), Research in organizational sociology (v. 3, pp. 1323-1382). Greenwich, CT: JAI Press.

Van-Manen, M. (2007). Phenomenology of practice. Phenomenology \& Practice, $1(1), 11-30$

Vasconcelos, M. E. S. M., \& Domingues, F. F. (2018). Ser quem eu quiser na Liberdade: práticas de resistência na ocupação da Praça da Liberdade em Belo Horizonte-MG. In Anais do 42ㅇ Encontro da Associação Nacional dos Programas de Pós-Graduação em Administração, Maringá, PR.

Webster, L., \& Mertova, P. (2007). Using narrative inquiry as research method: an introduction to using critical event narrative analysis in research on learning and teaching. London, UK: Routledge.

Wenger, E. (1998). Communities of practice: learning, meaning, and identity. Cambridge, UK: Cambridge University Press.

Wenger, E. (2011). Comunidades de práctica: aprendizaje, significado e identidad. Buenos Aires, Argentina: Paidós.

Wenger, E., McDermott, R., \& Snyder, W. (2002). Cultivating communities of practice: a guide to managing knowledge. Boston, MA: Harvard Business School Press.

Zioli, E. G. O., Rodrigues, F. S., Gaffuri, E. L., \& Ichikawa, E. Y. (2018). As práticas cotidianas e os processos de territorialização de assentados no Município de Querência do Norte-RN. In Anais do 42 Encontro da Associação Nacional dos Programas de Pós-Graduação em Administração, Maringá, PR.

Ariane Latoski

ORCID: https://orcid.org/0000-0002-5208-6921

Associate Researcher at the Universidade Positivo in the Doctoral Program in Administration; Post-Doctorate in the Master and Doctorate Program in Administration at Universidade Positivo.E-mail: ariane.latoski1@gmail.com

Eloy Eros da Silva Nogueira

ORCID: https://orcid.org/0000-0002-5234-496X

Professor and associated Researcher of the Research Group on Practices, Subjectivity, and Organizations, of the Master and Doctorate Program in Administration at Universidade Positivo. E-mail: esn.ipe777@gmail.com 